\title{
SUGGESTIONS FOR FUTURE STUDY OF RHETORIC AND MatTHew's Gospel
}

Author:

Craig S. Keener ${ }^{1,2}$

Affiliations:

${ }^{1}$ Department New

Testament, Palmer

Theological Seminary of

Eastern University, United

States of America

${ }^{2}$ Faculty of Theology, University of Pretoria,

South Africa

\section{Correspondence to:}

Craig Keener

email:

ckeener@eastern.edu

\section{Postal address:}

Palmer Seminary, 6 E.

Lancaster Avenue,

Wynnewood, PA 19096,

USA

\section{Keywords:}

biography; Gospels;

Matthew; rabbis; rhetoric

\section{Dates:}

Received: 12 Dec. 2009

Accepted: 04 Mar. 2010

Published: 18 Aug. 2010

How to cite this article:

Keener, C.S., 2010,

'Suggestions for future

study of rhetoric and

Matthew's Gospel',

HTS Teologiese Studies/

Theological Studies 66(1),

Art. \#812, 6 pages, DOI:

10.4102/hts.v66i1.812

\section{This article is available}

at:

http://www.hts.org.za

\section{Note:}

Prof. Dr Craig S. Keener

participates as a research associate in the research project 'Biblical Theology and Hermeneutics', directed by Prof. Dr Andries G. van Aarde, Honorary Professor of the Faculty of Theology at the University of Pretoria, South Africa.

(C) 2010. The Authors. Licensee: OpenJournals Publishing. This work is licensed under the Creative Commons Attribution License.

\section{ABSTRACT}

Because the Gospel writers addressed audiences in the Graeco-Roman world with various degrees of familiarity with standard rhetoric, rhetoric provides a helpful check on modern speculations about ancient speech and argument. Nevertheless, parallels with such rhetoric in Matthew, helpful as they are, tend to occur at a more general level and rarely on the level of specific wording. A more fruitful endeavour may be a comparison with rhetorical techniques in other ancient biographies. Beyond general urban Mediterranean rhetoric, however, a specific style of rhetoric emerges within Jesus' teachings. Because Matthew contains so much material about Jesus the Galilean sage, examining Jewish sage rhetoric proves particularly helpful for understanding his work and that of the traditional material on which he draws.

\section{INTRODUCTION}

The study of rhetoric has flourished in Pauline studies (e.g. Anderson 1999; Classen 2002; Pogoloff 1992; Smit Sibinga 1997:35-54; Winter 1997) and elsewhere. Although sometimes raised with respect to the Gospels (the work most often cited as seminal is Robbins 1992), its application has been limited and much room remains for further work. In this article, I merely offer some suggestions for directions for continued study. I will argue that while application of principles from Graeco-Roman handbooks will offer some new insights, study of Jewish sage rhetoric, though technically an 'old' approach, holds even greater promise for the future. I draw here especially on my work in my commentary on Matthew (Keener 2009a: passim, but especially xxv-1).

All persuasion is, of course, rhetorical in a general sense and one can use Graeco-Roman rhetorical categories to classify or evaluate much persuasion. But not all texts seem equally well designed for such categories, as will be clear from critical patristic comments, offered after the rise of the Second Sophistic, about biblical rhetoric. Styles of Graeco-Roman argumentation and many rhetorical devices pervaded public speech, whether in assemblies or on street corners, in Hellenised and Romanised cities; they therefore shaped the character of argumentation in such settings. Nevertheless, many geographic areas also retained elements of indigenous cultures or traditional rhetorics and we could expect a confluence of approaches, or even a dominance of traditional approaches, in these areas.

\section{GRAECO-ROMAN RHETORIC}

While Matthew's Gospel is (in my opinion) clearly Jewish, this conclusion need not entail the a priori irrelevance of Graeco-Roman rhetoric. If Matthew writes among Jewish followers of Jesus in urban Syria, perhaps Antioch, he could write for a somewhat Hellenised Jewish subculture; not only the Greek language in which he likely wrote, but also his adoption or adaptation of the Greek genre of biography, following Mark and probably other writers, allow for Greek influence. ${ }^{1}$ (It should go without saying that ancient biography is not identical to modern biography, although the latter ultimately developed from the former. $)^{2}$ We have numerous examples of surviving biographies from within a few decades after the Gospels, ${ }^{3}$ as well as some others ${ }^{4}$ much earlier.

Examining the literary techniques of rhetorically trained writers of histories and biographies could, therefore, provide useful insights into Matthew's own writing style ${ }^{5}$ and I sought to provide numerous such comparisons in my commentary on Matthew. ${ }^{6}$ Most ancient biographies, such as Matthew, tended

1.For the Gospels as ancient biography, see for example, Aune 1987:46-76, 2003:204; Balch 2004:948; Burridge 1992:191-219, 1998:121-122, 2000; Cross 2000:402-404; Dunn 2005b:173-174; Frickenschmidt 1997; Perkins 2007:2-11; Robbins 1992:10; Shuler 1982; Stanton 1974:117-136; Talbert 1977; Ytterbrink 2004 (for Luke). Also, compare Barr and Wentling 1984; Berschin 2003:653; and so forth. For aretological biography, see Wills 1997. Some of these writers (e.g. Stanton 1989:19) reverse an earlier scepticism toward the biographical proposal (see Stanton 1993:64, 2005:544-549).

2.Talbert (1977:2-3) observes that Strauss, Bultmann (see 1968:372, 2005:547) and their followers rejected the biographical category because they confused ancient with modern biography.

3.Such as those of Plutarch, Tacitus and Suetonius, and Josephus's autobiography. Plutarch and Suetonius are normally cited as the most obvious examples from this era (Kennedy 1978:139).

4.Notably Cornelius Nepos in the late-2nd century BCE.

5.For insights from rhetorical history for Acts (where it is much more directly relevant than in Matthew), see Rothschild 2004; for exploratory approaches to Greco-Roman rhetoric in some gospel materials, see, for example, Mack and Robbins 1989.

6.For example, in ancient biography, over 150 citations from Diogenes Laertius, nearly 80 from the pre-Christian writer Cornelius Nepos, roughly 50 from Plutarch's lives, over 60 from Arrian's life of Alexander, nearly 40 from Suetonius; in historiography, nearly 200 from Diodorus Siculus, nearly 170 from Dionysius of Halicarnassus and so forth. Among comparisons with rhetorically sophisticated writers, the index of my original Matthew commentary lists roughly 80 citations of Cicero, 37 of Theon, over 20 of the Rhetorica ad Herennium nearly 50 of Quintilian, over 50 of Isocrates, over 60 of Demosthenes and so forth. Admittedly, these references involve content as well as technique, hence are not all rhetorical or literary observations per se (many are more social). 
to be arranged more topically than chronologically. ${ }^{7}$ Like the Gospels, biographers frequently sought to teach moral lessons from their stories ${ }^{8}$; one might in a sense learn from great teachers of the past by proxy, as students of their recorded teachings (Robbins 1992:110-11). Theological perspectives, too, drove ancient works of these kinds. ${ }^{9}$ Some narrative techniques, such as suspense, appear in a variety of ancient narrative genres. ${ }^{10}$

These comparisons do not imply that we should think that Matthew had rhetorical training or necessarily even consciously imitated the elite biographers and historians whose works remain extant. They simply provide a concrete criterion for evaluation that is more culturally relevant than purely modern speculations about how ancients should have written. Thus one could compare with Graeco-Roman rhetoric various examples in Matthew's Gospel:

- After an introduction, speeches of praise could ideally address a person's genealogy (cf. Mt 1:2-16; Rhetorica ad Alexandrum 35, 1440b.23-24; see e.g. Tacitus Agricola 4). ${ }^{11}$

- Respectable ancestry was praiseworthy, hence could be used in introducing a person's life (e.g. Xenophon Ages. 1.2; Eunapius Lives 498; Gorgias Hel. 3). ${ }^{12}$

- Birth was often the first subject in an encomium, though one would elaborate on only the most important points (cf. Mt 1:18-25; Hermogenes Issues 46.14-17) 13; $^{13}$ after praising a king's country and family, a rhetorician would turn to praising his birth (Menander Rhetor 2.1-2, 371.3-4).

- Praising the virtue of Joseph and Mary fits ancient rhetorical emphasis on praiseworthy ancestry (see e.g. Gorgias $\mathrm{Hel}$. 3); 'upbringing' was a conventional element in praising a person's background (e.g. Menander Rhetor 2.1-2, 371.1723 , for the emperor; on nurture and training in encomia, see further Malina and Neyrey 1996:27-28). ${ }^{14}$

- Matthew 2:1-12 is comparable to rhetorical synkrisis, or comparison, of the new characters; although evident even in many Old Testament (OT) narratives, rhetoricians made deliberate and considered use of this technique. ${ }^{15}$

- As Matthew 6:1 offers a thesis illustrated by three examples (6:2-18), ancient rhetoricians often liked having three

7.For example Suetonius Aug. 9; Calig. 22.1; Nero 19.3; Görgemanns 2003; compare for example, the accidental repetition in Plutarch Alex. 37.4; 56.1. This contrast with the more chronological practice usually followed by historians (e.g. Thucydides 2.1.1; 5.26.1); when interested in chronology, Suetonius cites not biographers but historians (Calig. 8.3).

8.Cornelius Nepos 16 (Pelopidas), 1.1; Tacitus Agr. 1 (on Tacitus cf. Moore 1937:xiii); Burridge 1992:68-69, 150; compare Dihle 1991:367-374. Still, 'good' biographers were not supposed to risk falsifying events by flattery (Lucian Hist. 12). For ers were 12). For emphasis on moral lessons in ancient historiography more generally, see, or example, Polybius 1.1.1; Dionysius of Halicarnassus Ant. rom. 1.2.1; Valerius Maximus 2.pref.; Lucian Hist. 59; Fornara 1983:113-116; Marguerat 1999:28-29. or moralising asides, see, for example, Polybius 1.35.1-10; Diodorus Siculus 31.10.2. Dionysius of Halicarnassus Ant. Pom. 7.65.2; Cassius 1.5.4; Arrian Alex. 4.10.8; Cornelius Nepos 16 (Pelopidas), 3.1; see further in Sheeley 1992:56-93.

9.For example, Xenophon Anab. 5.2.24; Dionysius of Halicarnassus Ant. rom 8.56.1; compare Meister 2005:269; especially Squires 1993:15-20, 1998:38, citing Diodorus Siculus 1.1.3.

10.Not only novels (e.g. Heliodorus Eth. 1.1 [opening in the middle of a scene the background of which does not appear until 5:28-33], 2.11,2.25-4.21), but also other genres (e.g. Polybius Bk. 3 [end]; Cicero Verr. 2.5.5.10-11).

11. One starts with pedigree both for people and animals (Rhetorica ad Alexandrum 35 $1440 \mathrm{~b}$ 24-29). One's background was an important element in biography; see for example, Suetonius Aug. 1-2; Feldman 2002. Some Jewish traditions may have differed by region (cf. Kalmin 1996).

12.Ancients inspected pure lineage for participation in priesthoods (e.g. Hermogenes Issues 65.4-6; Frankfurter 1998:199) and other public honours (cf. even Indian philosophers in Philostratus Vit. Apoll. 2.30).

13.Others, though, might start with one's city (Menander Rhetor 2.1-2, 369.18-370.8) before discussing one's family background (370.9-28), birth (370.28-371.17), upbringing (371.17-23) and education (371.23-372.2). For 'origin and birth' in ancient encomia, see Malina and Neyrey 1996:24-26.

14.Parentage could also be used to deride one (e.g. Ps.-Cicero Invective Against Sallust 5.13)

15.See comments on the technique in Anderson 2000:110-111; Aune 2003:110; Keener 2003:916-917, 1183-1184, with documentation. See for example Keener 2003:916-917, 1183-1184, with documentation. See for example
Dionysius of Halicarnassus Dem. 33; especially Plutarch's parallel lives, for Dionysius of Halicarnassus Dem. 33; esp
example Comparison of Lucullus and Cimon. examples to support a rhetorical thesis (Quintilian Inst. 4.5.3. Pliny Ep. 2.20.9; cf. Cicero Pro Murena $5.11^{16}$; though skilled rhetoricians complained about those who always managed to fit everything into three points; Cicero Quinct. 10.35).

- The threefold repetition of sou, 'your', at the end of successive clauses in Matthew 6:9-10 fits rhetorical antistrophe or epiphora (on which see e.g. Anderson 1999:163; Rowe 1997:131)

- Witty repartee was a valued skill ${ }^{17}$ and (as in the Gospels) could incur the enmity of the interlocutors at whose expense the wit succeeded (e.g. Philostratus Hrk. 33.8-9).

- In Matthew 12:43-45, Jesus essentially returns with interest his opponents' demonisation charge. Returning charges was conventional in forensic rhetoric. ${ }^{18}$

- Vice lists (Mt 15:19) are common among rhetoricians, ${ }^{19}$ though also in Jewish sources, ${ }^{20}$ among Stoics ${ }^{21}$ and other philosophers. ${ }^{22}$

- Rhetoricians could appreciate as rhetorical antithesis ${ }^{23}$ the contrast between the one exalting him- or herself being humbled and the one humbling him- or herself being exalted (Mt 23:12) ${ }^{24}$ though the basic idea appears in Jewish sources before significant influence from Graeco-Roman rhetorical forms. ${ }^{25}$

- 'Never before' (Mt 24:21) was suitable evocative hyperbole, sometimes found in historians and speeches. ${ }^{26}$

- The repetition of 'not pass away' in Matthew 24:35 appears comparable to rhetorical antistrophe (Black 1991:86; Lee 1997:779; Rowe 1997:131).

Nevertheless, the heavy dominance of traditional materials in Matthew means that many of the forms we find there, such as story parables and Jesus' sayings as a sage, do not fit ordinary Graeco-Roman rhetoric. Certainly forms found in GraecoRoman rhetoric can offer a context for the sorts of forms in which traditions were passed on (see Mack \& Robbins 1989), including, for example, the ways that narrators felt free to elaborate, expand and condense their materials. ${ }^{27}$ My point, however, is that Jesus'

16.Some also detect a common triple pattern in oral traditions (Dunn 2005:115)

17.For short narratives climaxing in the protagonist's incisive quip, see, for example, Plutarch Ages. 21.4-5

18.See, for example, Rhetorica ad Alexandrum 36, 1442b.6-9; Cicero Or. Brut. 40.137; De or. 3.204 (also metastasis in Anderson, Glossary, 72-73); for 40.137; De or. 3.204 (also metastasis in Anderson, Glossary, 72-73); for \$96; Aeschines Fals. leg. 3; Ctes. 113, 156, 259; Dionysius of Halicarnassus Lys. \$96; Aeschines Fals. leg. 3; Ctes. 113, 156, 259; Dionysius of Halicarnassus Lys.
24; Cicero Sest. 37.80; Cael. 13.31, 24.60; Quinct. 3.11-9.33; further discussion in Keener 2003:752-753, 2008:244-246.

19.For example, Rhetorica ad Alexandrum 36, 1442a.13-14; Cicero Pis. 27.66; Cat 2.4.7, 2.5.10, 2.10.22, 25; Cael. 22.55; Phil. 3.11.28, 8.5.16; Mur. 6.14 (negated) Ps.-Cicero Invect. Sall. 6.18; Dio Chrysostom Or. 1.13, 3.53, 4.126, 8.8, 32.28,91, 33.23,55, 34.19; Fronto Nep. Am. 2.8; Lucian Posts 4; Charon 11, 15; Tim. 28; Nigr. 17; Maximus of Tyre $5.7 ; 36.2$.

20.For example, Jeremiah 7:9; Ezekiel 18:6-8, 11-13; Hosea 4:2, 4 Q477 frg. 2, col. 2 line 4; Wis 14:22-27 (esp. 14.25-26): Philo Posterity 52. Compare also col. 2, line 4; Wis 14:22-27 (esp. 14:25-26); Philo Posterity 52. Compare also Timothy 3:1-5; for Gentile equivalents, Hesiod W.D. 181-201; Lucian Men. 11-12)

21.For example, Seneca Dial. 9.2.10-12; Epictetus Diatr. 2.8.23; Arius Didymus Epit. 2.7.5b, pp. 12-13.2-12, 2.7.10b, pp. 58-59.32-60-61.1, 2.7.10b, pp. 60-61.1-7, 2.7.10e, pp. 62-63.14-19, 2.7.11e, pp. 68-69.17-20; Diogenes Laertius 2.93

22.For example, Plato Law 1.649D; Aristotle E.E. 2.3.4, 1220b-1221a; Ps.-Aristotle V.V. 1249a-1251b; Diogenes Ep. 36; Philostratus Ep. Apoll. 43; lamblichus Vit. Pyth 17.78

23.See Rhetorica ad Alexandrum 26, 1435b.25-39; Cosby 1991:216-217 (citing Aristotle Rhet. 3.9.7-8; Quintilian Inst. 9.3.81); MacDowell 1982:18-19; Rowe 1997:142. Note especially reasoning by contraries in Rhetorica ad Herennium 1997:142.

24.Even the specific idea appears occasionally; see Xenophon Anab. 6.3.18; compare Seneca Ep. Lucil. 94.73-74; Josephus Ant. 19.296.

25.See, for example, Psalms 18:27; Isaiah 2:11-12,17, 5:15, 13:11; Ezekiel 21:26 Daniel 4:37; antithesis more generally characterises much Jewish wisdom, for example, in Proverbs.

26.Compare Dionysius of Halicarnassus Thuc. 19; Thucydides 2.94.1; 8.96.1; Cicero Verr 25.72 189. Philostratus Hrk. 24.2. compare 'never again' in Silius Italicus 9.183; Thucydides on the 'greatest' war in Thucydides 1.1.1-2, 1.21.2, 1.23.1-2.

27.See, for example, Theon Progymn. 3.224-40, 4.37-42, 80-82; compare Longinus On the Sublime 11.1; Hermogenes Progymn. 3.On Chreia, 7; Aphthonius Progymn. 3.On Chreia, 23S, 4R. 
speeches in Matthew do not resemble Graeco-Roman speeches. Modern scholars may try to force them into rhetorical outlines, but a simple comparison with the Diaspora speeches in Acts will illustrate how poorly Matthew's speeches fit this pattern. ${ }^{28}$ Paul's letters abound with Graeco-Roman rhetorical devices, but those we find in Jesus' speech in Matthew also appear in traditional Jewish texts, with far fewer examples of distinctively Greek forms of argumentation.

I was asked to add an excursus on rhetoric to the recent (2009) rerelease of my Matthew commentary (Keener 2009a:viii-x, xxv-1). I came to this project after working through Acts and some of Paul's letters in light of Graeco-Roman rhetoric (Keener 2005, $2008,2009 \mathrm{~b}$, in press); while I found abundant connections with rhetoric in the works of Luke and Paul, I found the approach much less fruitful for Matthew. By this observation, I do not mean to discourage scholars from pursuing what fruit they may find here; I only would urge caution informed by a wider range of comparisons than rhetorical handbooks or Gentile speeches would offer.

\section{JEWISH SAGE RHETORIC}

Examining Matthew's Jewish context is hardly new, but, in view of the current interest in rhetorical studies, placing the teachings of Matthew's Jesus in the context of the teachings of Jewish sages' rhetoric is a topic that might yield interesting fruit. Unfortunately, we lack Jewish rhetorical handbooks comparable to Greek and Roman ones; one is hard-pressed to locate even collections of Jewish speeches per se.

We do, however, have many collections of Palestinian Jewish teachings, from Proverbs, to Sirach, to the later rabbis. Scholars wishing to compile extensive observations about Jewish sages' rhetorical techniques (at least some of which will be comparable to Greek and Roman analogues) may thus start there, providing a service to those who wish to use such observations. Even the earliest rabbinic literature is, of course, later than our period (just as Sirach is earlier), but where scholars may observe matters of continuity between Sirach and later rabbis, or even between Jesus (who did not significantly influence later rabbinic rhetoric) and the rabbis, we may infer some patterns of discourse that remained. Scholars are in an increasingly better position to identify the antiquity of some rabbinic traditions today through the continuing work of David Instone-Brewer, who is applying the most refined and developed form of Jacob Neusner's approach to evaluate the development of rabbinic traditions (Instone-Brewer 2004). Rhetoric, of course, often reflects the period of redactors rather than traditions, so the issue of continuity with earlier sources is an important one.

Here I wish merely to list several examples to suggest ways that the examination of Jewish rhetoric may be helpful:

- Although beatitudes (e.g. Mt 5:3-12) appear elsewhere in the Mediterranean world, ${ }^{29}$ they were more common in Jewish rhetoric, both in Scripture ${ }^{30}$ and subsequently. ${ }^{31}$

28.I have also changed my earlier position in light of recent scholarship and doubt that one can outline Paul's letters like speeches; see now discussion in, for example, Anderson 1999:114-127, 280-281; Bird 2008:374-379; Classen 2002:6, 23; Porter 1997:541-561 (esp. 562-567); Reed 1997.

29.For example, Contest of Homer and Hesiod 322; Homeric Hymn 25.4-5; Pindar Threnoi fr. 137 (in Clem. Alex. Strom. 3.3.17, using oblios); Polybius 26.1.13 (using makarios); Musonius Rufus frg. 35, p. 134; Apollonius King of Tyre 31; Babrius 103.20-21; Philostratus Hrk. 4.11; Porphyry Marc. 16.276-77. For makarios in Stoic and Christian literature, see Vorster 1990.

30.See, for example, Psalms 40:4, 41:1, 65:4, 84:4-5,12, 94:12, 112:1, 119:1-2, 128:1; Isaiah 56:2; Jeremiah 17:7; Daniel 12:12; Bar 4:4; with a different term, Jdt 13:18, 14:7, 15:10. The term makarios appears 66 times in the LXX, including 25 times in the Psalms (including 1:1, 2:12, 31:1-2=32:1-2), 11 times in Sirach (14:1$2,20,25: 8-9,26: 1,28: 19,31: 8,34: 15,48: 11,50: 28$ ) and four times in Proverbs ( $P r$ $3: 13,8: 34,20: 7,28: 14)$

31.For example, 1 En. 99:10; 2 En. 42.6-14, 44:5. Ps. Sol. 4:23, 5:16, 6:1, 10:1, 17:44, 18:6; 4 Macc 7:15,22, 10:15, 17:18, 18:9; Jos. Asen 16:14/7, 19:8, MSS Sipra VDDeho. par. 5.44.1.1; b. Ber. 61b; Hag. 14b; Hor. 10b, bar. At Qumran, see 4 Q525 (see Viviano 1992, 1993a, 1993b). In early Christianity, makarios appears
- Jewish teachers regularly distinguished 'light' and 'heavy' commandments (Mt 23:23; cf. Mt 5:19; e.g. Sipra VDDeho. par. 1.34.1.3; 12.65.1.3; Dalman 1929:64; Flusser 1988:496).

- Early Jewish rhetoric often includes phrases similar to 'You have heard it said,' often 'what was said' or 'as it is said' (cf. Mt 5:21, 27, 31, 33, 38, 43). ${ }^{32}$

- Lust hyperbolically constituting adultery (Mt 5:28). ${ }^{33}$

- The warning that it would be 'measured' to one as one measured to others (Mt 7:2; Lk 6:38). ${ }^{34}$

- Removing the beam from one's eye before trying to remove the chip from another's (Mt 7:3-5; Lk 6:41-42); this might be a figure of speech, attested in $b$. 'Arakin 16b; b. B.B. 15b (Vermes 1993:80; other texts in Lachs 1987:137), if that is not a polemical distortion of Jesus' teaching.

- The phrase, 'To what shall I/we compare?' (Mt 11:16; Lk 7:31) was common in Jewish rhetoric, especially to introduce parables. ${ }^{35}$

- The phrase 'So-and-so is like' (Mt 11:16, 13:24, 25:1; cf. also Mk 4:26,31, 13:34; Lk 6:48-49) is common in Jewish rhetoric. ${ }^{36}$

- Like many of Jesus' parables in the Gospels, early Jewish parables usually have interpretations (see Johnston 1977:561-562, 565-567, 637-638; Stern 1991:24; Vermes 1993:92-99; earlier, cf. Judges 9:16-20; 2 Samuel 12:7-9).

- More generally, proverbs and riddles continued among sages of Jesus' day (cf. Gottlieb 1990:152-164), ${ }^{37}$ although these are not uniquely Jewish or Eastern (cf. e.g. classical uses, Gärtner 2008).

- Jewish teachers typically employed the rhetorical techniques of hyperbole and rhetorical overstatement (e.g. m. Ab. 2:8; $A b$. R. Nat. $36 \mathrm{~A}$ ), though again these were by no means limited to them. ${ }^{38}$

- Matthew's periphrastic 'kingdom of heaven' appears in some other early Jewish sources. ${ }^{39}$

- The first half of the Lord's Prayer closely echoes the Kaddish (as well as the language of other early Jewish prayers). ${ }^{40}$

(Footnote 31 cont...)

about 50 times in the New Testament (NT) and 40 times in the Apostolic Fathers (Matthew comprises roughly a quarter of NT uses).

32. Compare, for example, 1QpHab 6.2; 1QM 11.5-6. CD 4.13, 19-20, 6.13, 7.8.14, 8.9,14, 9.7-9, 10.16; m. Ab. 1:18, 2:13; Mek. Pisha 1.70-71; Ab. R. Nat. 36 A. cf. $8.9,14,9.7-9,10.16 ; m$. Ab. 1:18, 2:13;
'they do X, but Moses said Y' (CD 5.18).

33.See Test. Iss. 7:2; Reub. 4:8; b. Nid. 13b, bar.; Shab. 64ab; p. Hallah 2:1, §10; Lev. Rab. 23:12; Pesiq. Rab. 24:2; further, Keener 1991:16-17. Jesus may read Exodus 20:14 in light of Exodus 20:17.

34.Many compare the Jewish maxim, 'By the measure by which one metes it is measured to one' (judgment in the present era in $m$. Sot 1:7; $b$. Sot. 8b; Pesiq. Rab. 39:2; more fully, Bivin 1991. Dalman 1929.225. Davies and Allison 1988:670; Smith 1951:135). Perhaps only one stream of Jewish tradition applied it to the Day Smith 1951:135). Perhaps only one stream of Jewish tradition applied it to the Day
of Judgement as Jesus does (cf. Rüger 1969), but it is at least implied elsewhere: a of Judgement as Jesus does (cf. Rüger 1969), but it is at least implied elsewhere: a
person judged mercifully by another ('with the scale weighted in my favor') prayed that God would also judge the other mercifully at the Judgement (Ab. R. Nat. 8A).

35.See m. Ab. 3:17; Suk. 2:10; tos. Ber. 1:11, 6:18; B.K. 7:2-4; Hag. 2:5; Sanh. 1:2, 8:9; Sipra Shemini Mekhilta deMiluim 99.2.5; Behuq. pq. 2.262.1.9; Sipre Num. 84.2.1, 93.1.3: Sipre Deut. 1.9.2, 1.10.1, 308.2.1, 308.3.1, 309.1.1, 309.2.1; ARN $1,2,6,8,9,11,14,16,19,23,24,27,28,31 \mathrm{~A}, 2,10,4, \$ 14,8, \$ 24,924,12,29$

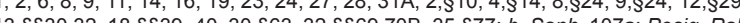
( ah. 1:2, 3:8, 14:5, 27:6; Pesiq. Rab Kah. Sup. 1:11, 3:2, 7:3; compare Bultmann 1968:179; Johnston 1977:531, 630

36.See tos. Suk. 2:6; Sipra Shemini Mekhilta deMiluim 99.2.2; Behuq. pq.3.263.1.5, 8; Sipre Num. 84.1.1, 86.1.1, 89.4.2; Sipre Deut. 3.1.1, 11.1.2, 26.3.1, 28.1.1, 29.4.1, 36.4.5, 40.6.1, 43.8.1, 43.16.1, 45.1.2, 48.1.3, 53.1.3, 306.4.1, 306.7.1, 309.5.1, 312.1.1, 313.1.1, 343.1.2, 343.5.2; p. Taan. 2:1,\$11; Lev. Rab. 27:8; compare Jeremias 1972:101; Johnston 1977:531; Smith 1951:179; Vermes 1993:92.

37.For many of Jesus' sayings as proverbial, see, for example, Damschen 2008:81.

38. Greek and Roman audiences were also comfortable with these figures of speech (cf. Rhetorica ad Alexandrum 11, 1430b.16-19; Rhetorica ad Herennium 4.33.44; Cicero Orator 40.139; Quintilian Inst. 8.6.73-76; Aristotle Rhet. 3.11.15; Demetrius Style 2.124-127, 3.161; further Anderson 2000:122-124), though this rhetoric may have been disseminated more commonly in the marketplace (cf. e.g. PGM 36.69 , $134,211-212,320$ ) than in deliberative speeches. For examples of hyperbole, see Dionysius of Halicarnassus Demosth. 18, with Isaeus 20; Philostratus V.A. 8.7; Philostratus Hrk. 48.11

39.For example Sipra Qed. pq. 9.207.2.13; p. Kid. 1:2,\$24. This is commonly pointed out, both by scholars of Judaism (e.g. Bonsirven 1964:7, Marmorstein 1968:93; Moore 1971:1:119) and by NT scholars (e.g. Goppelt 1981:1:44).

40.For the Kaddish, see Bonsirven 1964:133; Davies and Allison 1988:595; Hill 1972:136-137; Jeremias 1964:98, 1971:21; Luz 1989:371; Moore 1971:2:213 
- 'Mysteries of the kingdom' (Mt 13:11) may echo language from Daniel 2:44-47.41

- The Pharisees' divorce question reflects a debate among Pharisaic schools from Jesus' day (even more clearly in Matthew than in Mark). ${ }^{42}$

- 'Son of Man' (in all the Gospels) is a specifically Semitic construction. ${ }^{43}$

- 'Moving mountains' may have been a Jewish metaphor for accomplishing what was difficult or virtually impossible (though rabbis, who preserve it, apply it especially to labour in Torah). ${ }^{44}$

- Jewish teachers debated among themselves which commandment was the 'greatest' (Mt 22:36). ${ }^{45}$

- Jesus links the two 'greatest' commandments on the basis of the common opening expression we'ahavta ('You shall love'; with Diezinger 1978; Flusser 1988:479); this linkage reflects a common Jewish interpretive technique. ${ }^{46}$

- Later Babylonian Jewish teachers, not likely influenced by Jesus, could depict what was impossible or close to impossible as 'an elephant passing through a needle's eye' (Abrahams 1924:208; Bailey 1980:166; Dalman 1929:230; Jeremias 1972:195; they cite, for example, b. Ber. 55b; B.M $38 \mathrm{~b}$ ); in Palestine, where the largest animal was a camel (cf. b. Ket. 67a), this expression seems more logical. ${ }^{47}$

- Current Pharisaic debates about purity with respect to the inside or outside of cups. ${ }^{48}$

One could go on at much greater length, but these examples should illustrate the particularly Jewish setting of Matthew's tradition and sometimes his redaction. After centuries of Hellenisation, even Palestinian Jewish works could reflect Greek influences; purely gentile Greek sources, however, do not reflect such Jewish motifs. Those attending to Matthew's rhetoric, therefore, must look beyond Graeco-Roman rhetorical handbooks to the rhetoric of Jewish sages. This rhetoric is not available in ancient handbooks, and interpreters must compile such works or immerse themselves in ancient Jewish sources.

\section{CONCLUSION}

Because the Gospel writers addressed audiences in the Graeco-Roman world with various degrees of familiarity with standard rhetoric, rhetoric provides a helpful check on modern speculations about ancient speech and argument. Nevertheless, the form of rhetoric we find in Graeco-Roman handbooks, while worth exploring, will probably yield more limited benefits to Matthean studies than it has in Pauline or Lukan studies. One

(Footnote 41 cont...)

Perrin 1976:28-29; Smith 1951:136; Vermes 1984:43; for the Eighteen Benedictions, see Bivin 1992.

41.Compare Evans 2003; Niskanen 2004; Witherington 1990:242. For the 'revealing' of 'mysteries' in Qumran texts, see, for example, $1 \mathrm{QpHab} 7.4-5,13-14 ; 1 \mathrm{QH}$ 2.13-14, 9.23-24, 11.9-10,16-17, 12.11-13; 1QS 8.1-2,12, 9.13,17-19; 4Q418 compare 1QS 5.11-12, 11.3-5; 1QM 3.9,17.9; more fully, see Brown 1968

42.Compare (esp. with reference to Matthew), for example, Argyle 1963:51-52; Dobschütz 1995:33; Filson 1960:206; Gundry 1982:377; Ilan 1996:142; Overman 1996:82, 279. For the Pharisaic debate, see $m$. Git. 9:10; Sipre Deut. 269.1.1. The more liberal interpretation appears in Josephus Ant. 4.253 (relevant for a Hellenistic audience).

43. With for example Jeremias 1971:260-262, regardless of the other debates surrounding its meaning.

44.For example Ab. R. Nat. 6A, 12,§29B; b. Ber. 63b; Sanh. 24a. So also Jeremias 1971:161; Nineham 1977:305; compare Test. Sol. 23:1, possibly derivative.

45.Later rabbis often discussed the question of the 'greatest' commandment; see, for example, Hagner 1993-1995:646. R. Akiba valued love of neighbour as the greatest (Sipra Qed. pq. 4.200.3.7; Gen. Rab. 24:7).

46. Gezerah sheva (perhaps borrowed from Hellenism, but notably common in Jewish interpretation; e.g. Mekilta Nez. 10.15-16,26,38, 17.17; Pisha 5.103; cf. CD 7.1520; Keener 2003:305, 1184, for further sources).

47.The expression persists as late as Qur'an 7.40, though this reference (involving eternal life) might evoke the tradition of Jesus' usage.

48.McNamara 1983:197 (citing m. Kel. 25:1-9; Par. 12:8; Toh. 8:7; see also m. Ber 8:2; the houses material in b. Shab. 14b, bar.); Neusner 1976:492-494. fruitful area of research for Gospel studies may be comparison with rhetorical techniques in other ancient biographies, an area where much work remains to be done (in part because the biographic genre of Matthew has emerged as a dominant view only in recent decades).

Beyond general urban Mediterranean rhetoric, however, a specific style of rhetoric emerges within Jesus' teachings in Matthew's Gospel. Because Matthew contains so much material about Jesus the Galilean sage, examining Jewish sage rhetoric will prove particularly helpful for understanding his work.

\section{REFERENCES}

Abrahams, I., 1924, Studies in Pharisaism and the Gospels, 2nd ser., Cambridge University Press, Cambridge.

Anderson Jr, R.D., 1999, Ancient rhetorical theory and Paul, Contributions to Biblical Exegesis and Theology 18, rev. edn., Peeters, Leuven.

Anderson Jr, R.D., 2000, Glossary of Greek rhetorical terms connected to methods of argumentation, figures and tropes from Anaximenes to Quintilian, Peeters, Leuven.

Argyle, A.W., 1963, The Gospel according to Matthew, Cambridge University Press, Cambridge.

Aune, D.E., 1987, The New Testament in its literary environment, Library of Early Christianity 8, Westminster, Philadelphia.

Aune, D.E., 2003, The Westminster dictionary of New Testament $\mathcal{E}$ early Christian literature $\mathcal{E}$ rhetoric, Westminster John Knox, Louisville.

Bailey, K.E., 1980, Through peasant eyes: More Lucan parables, their culture and style, Eerdmans, Grand Rapids.

Balch, D.L., 2004, 'Gospels (literary forms)', in H. Cancik, H. Schneider \& C. F. Salazar (eds.), Brill's new Pauly: Encyclopaedia of the ancient world, vol. 5, pp. 947-949, Brill, Leiden.

Barr, D.L. \& Wentling, J.L., 1984, 'The conventions of classical biography and the genre of Luke-Acts: A preliminary study', in C.H. Talbert (ed.), Luke-Acts: New perspectives from the Society of Biblical Literature seminar, pp. 63-88, Crossroad, New York.

Berschin, W., 2003, 'Biography: Late antiquity', in H. Cancik, H. Schneider \& C.F. Salazar (eds.), Brill's new Pauly: Encyclopaedia of the ancient world, vol. 2, pp. 653-655 Brill, Leiden.

Bird, M.F., 2008, 'Reassessing a rhetorical approach to Paul's letters', Expository Times 119(9), 374-379.

Bivin, D., 1991, 'A measure of humility', Jerusalem Perspective 4, $13-14$

Bivin, D., 1992, 'Prayers for emergencies', Jerusalem Perspective $5,16-17$.

Black, C.C., 1991, 'An oration at Olivet: Some rhetorical dimensions of Mark 13', in D.F. Watson (ed.), Persuasive artistry: Studies in New Testament rhetoric in honor of George A. Kennedy, JSNT Suppl. 50, pp. 66-92, Sheffield Academic Press, Sheffield

Bonsirven, J., 1964, Palestinian Judaism in the time of Jesus Christ, Holt, Rinehart \& Winston, New York.

Brown, R.E., 1968, The Semitic background of the term 'mystery' in the New Testament, Fortress, Philadelphia.

Bultmann, R., 1968, The history of the synoptic tradition, 2nd edn., Basil Blackwell, Oxford.

Bultmann, R., 2005, 'The message of Jesus and the problem of mythology', in J.D.G. Dunn \& S. McKnight (eds.), The historical Jesus in recent research, pp. 531-542, Eisenbrauns, Winona Lake.

Burridge, R.A., 1992, What are the Gospels? A comparison with Graeco-Roman biography, Society for New Testament Studies Monograph Series 70, Cambridge University, Cambridge.

Burridge, R.A., 1998, 'About people, by people, for people: Gospel genre and audiences', in R. Bauckham (ed.), The Gospels for all Christians: Rethinking the Gospel audiences, pp. 113-146, Eerdmans, Grand Rapids. 
Burridge, R.A., 2000, 'Biography, ancient', in C.A. Evans \& S.E. Porter (eds.), Dictionary of New Testament background, pp. 167-170, InterVarsity, Downers Grove.

Classen, C.J., 2002, Rhetorical criticism of the New Testament, Brill Academic Publishers, Boston.

Cosby, M.R., 1991, 'Paul's persuasive language in Romans 5', in D.F. Watson (ed.), Persuasive artistry: Studies in New Testament rhetoric in honor of George A. Kennedy, JSNT Suppl. 50, pp. 209-226, Sheffield Academic Press, Sheffield.

Cross, A.R., 2000, 'Genres of the New Testament', in C.A. Evans \& S.E. Porter (eds.), Dictionary of New Testament background, pp. 402-411, InterVarsity, Downers Grove.

Dalman, G., 1929, Jesus-Jeshua: Studies in the Gospels, Macmillan, New York.

Damschen, G., 2008, 'Proverbs. III. Classical antiquity', in H. Cancik, H. Schneider \& C.F. Salazar (eds.), Brill's new Pauly: Encyclopaedia of the ancient world, vol. 12, pp. 80-81, Brill, Leiden.

Davies, W.D. \& Allison, D.C. Jr., 1988-1997, A critical and exegetical commentary on the Gospel according to Saint Matthew, International Critical Commentaries, 3 vols, T. \& T. Clark, Edinburgh.

Diezinger, W., 1978, 'Zum Liebesgebot Mk xii,28-34 und Parr [For the love commandment Mk xii, 28-34 and Parr]', Novum Testamentum 20, 81-83.

Dihle, A., 1991, 'The Gospels and Greek biography', in P. Stuhlmacher (ed.), The gospel and the Gospels, pp. 361-386, Eerdmans, Grand Rapids.

Dobschütz von, E., 1995, 'Matthew as rabbi and catechist (1928)', in G. Stanton (ed.), The interpretation of Matthew, 2nd edn., pp. 27-38, T. \& T. Clark, Edinburgh.

Dunn, J.D.G., 2005, A new perspective on Jesus: What the quest for the historical Jesus missed, Baker, Grand Rapids.

Dunn, J.D.G., 2005, 'The tradition', in J.D.G. Dunn \& S. McKnight, The historical Jesus in recent research, pp. 167-184, Eisenbrauns, Winona Lake.

Evans, C.A., 2003, 'Defeating Satan and liberating Israel: Jesus and Daniel's visions', Journal for the Study of the Historical Jesus 1(2), 161-170.

Feldman, L.H.,2002,'Philo's view of Moses'birthand upbringing', Catholic Biblical Quarterly 64(2), 258-281.

Filson, F.V., 1960, A commentary on the Gospel according to St. Matthew, Harper \& Row, New York.

Flusser, D., 1988, Judaism and the origins of Christianity, Magnes Press, Hebrew University, Jerusalem.

Fornara, C.W., 1983, Thenature of history in Ancient Greece and Rome, University of California Press, Berkeley.

Frankfurter, D., 1998, Religion in Roman Egypt: Assimilation and resistance, Princeton University, Princeton.

Frickenschmidt, D., 1997, Evangelium als Biographie. Die vier Evangelien im Rahmen antiker Erzählkunst [Gospel as biography. The four Gospels in the context of ancient narrative], Texte und Arbeiten zum neutestamentlichen Zeitalter 22, Francke, Tübingen.

Gärtner, H.A., 2008, 'Riddles. III. Classical antiquity', in H. Cancik, H. Schneider \& C. F. Salazar (eds.), Brill's new Pauly: Encyclopaedia of the ancient world, vol. 12, pp. 589-591, Brill, Leiden.

Goppelt, L., 1981-1982, Theology of the New Testament, 2 vols, Eerdmans, Grand Rapids.

Görgemanns, H., 2003, 'Biography: Greek', in H. Cancik, H. Schneider \& C.F. Salazar (eds.), Brill's new Pauly: Encyclopaedia of the ancient world, vol. 2, pp. 648-651, Brill, Leiden.

Gottlieb, I.B., 1990, 'Pirqe Abot and biblical wisdom', Vetus Testamentum 40(2), 152-164.

Gundry, R.H., 1982, Matthew: A commentary on his literary and theological art, Eerdmans, Grand Rapids.

Hagner, D.A., 1993-1995, Matthew, Word Biblical Commentary 33AB, Word, Dallas.

Hill, D., 1972, The Gospel of Matthew, New Century Bible, Eerdmans, Grand Rapids.

Ilan, T., 1996, Jewish women in Greco-Roman Palestine, J.C.B. Mohr, Tübingen.
Instone-Brewer, D., 2004, Traditions of the rabbis from the era of the New Testament, Eerdmans, Grand Rapids.

Jeremias, J., 1964, The prayers of Jesus, Fortress, Philadelphia.

Jeremias, J., 1971, New Testament theology, Charles Scribner's Sons, New York.

Jeremias, J., 1972, The parables of Jesus, 2nd rev. edn., Charles Scribner's Sons, New York.

Johnston, R.M., 1977, 'Parabolic interpretations attributed to Tannaim', PhD thesis, Hartford Seminary Foundation.

Kalmin, R., 1996, 'Genealogy and polemics in rabbinic literature of late antiquity', Hebrew Union College Annual 67, 77-94.

Keener, C.S., 1991, ... And marries another: Divorce and remarriage in the teaching of the New Testament, Hendrickson, Peabody.

Keener, C.S., 2003, The Gospel of John: A commentary, 2 vols, Hendrickson, Peabody.

Keener, C.S., 2005, 1 E 2 Corinthians, New Cambridge Bible commentary, Cambridge University Press, Cambridge.

Keener, C.S., 2008, 'Some rhetorical techniques in Acts 24:2-21', in S.E. Porter (ed.), Paul's world, PAST 4, pp. 221-251, Brill, Leiden.

Keener, C.S., 2009a, The Gospel of Matthew: A socio-rhetorical commentary, Eerdmans, Grand Rapids.

Keener, C.S., 2009b, Romans, New Covenant Commentary Series, Cascade, Eugene.

Keener, C.S., (in press), 'Acts', 3 vols, Hendrickson, Peabody.

Kennedy, G.A., 1978, 'Classical and Christian source criticism', in W.O. Walker, Jr. (ed.), The relationships among the gospels: An interdisciplinary dialogue, pp. 125-155, Trinity University Press, San Antonio.

Lachs, S.T., 1987, A rabbinic commentary on the New Testament: The Gospels of Matthew, Mark, and Luke, KTAV, Hoboken.

Lee, J.A.L., 1997, 'Translations of the Old Testament, I. Greek', in S.E. Porter (ed.), Handbook of classical rhetoric in the Hellenistic Period 330 B.C.-A.D. 400, pp. 775-783, Brill, Leiden.

Luz, U., 1989, Matthew 1-7: A commentary, Fortress, Minneapolis.

MacDowell, D.M., 1982, 'Introduction', in Gorgias, Helen, pp. 9-19, Bristol Classical Press, Bristol.

Mack, B.L. \& Robbins, V.K., 1989, Patterns of persuasion in the gospels, Polebridge, Sonoma.

Malina, B.J. \& Neyrey, J.H., 1996, Portraits of Paul: An archaeology of ancient personality, Westminster John Knox, Louisville.

Marguerat, D., 1999, La Première Histoire du Christianisme (Les Actes des Apôtres) [The first history of Christianity (The Acts of the Apostles)], LD 180, Les Éditions du Cerf, Paris.

Marmorstein, A., [1927] 1968, The old rabbinic doctrine of God: The names and attributes of God, KTAV, New York.

McNamara, M., 1983, Palestinian Judaism and the New Testament, Michael Glazier, Wilmington.

Meister, K., 2005, 'Herodotus', in H. Cancik, H. Schneider \& C.F. Salazar (eds.), Brill's new Pauly: Encyclopaedia of the ancient world, vol. 6, pp. 265-271, Brill, Leiden.

Moore, C.H., 1937, 'Introduction: Life and works of Tacitus', in Tacitus, The Histories, 2 vols, Loeb Classical Library, 1:viixiii, Heinemann, London.

Moore, G.F., [1927] 1971, Judaism in the first centuries of the Christian era, 2 vols, Schocken Books, New York.

Neusner, J., 1976, "First cleanse the inside"', New Testament Studies 22, 486-495.

Nineham, D.E., 1977, Saint Mark, Westminster, Philadelphia.

Niskanen, P., 2004, 'Kingdoms, dominions, and the reign of God', Bible Today 42(6), 343-348. 
Overman, J.A., 1996, Church and community in crisis: The Gospel according to Matthew, Trinity Press International, Valley Forge.

Perkins, P., 2007, Introduction to the synoptic Gospels, Eerdmans, Grand Rapids.

Perrin, N., 1976, Jesus and the language of the kingdom: Symbol and metaphor in New Testament interpretation, Fortress, Philadelphia.

Pogoloff, S.M., 1992, Logos and Sophia: The rhetorical structure of 1 Corinthians, Society of Biblical Literature Dissertation Series 134, Scholars, Atlanta.

Porter, S.E., 1997, 'Paul of Tarsus and his letters', in S.E. Porter (ed.), Handbook of classical rhetoric in the Hellenistic Period 330 B.C.-A.D. 400, pp. 533-585, Brill, Leiden.

Reed, J.T., 1997, 'The epistle', in S.E. Porter (ed.), Handbook of classical rhetoric in the Hellenistic Period 330 B.C.-A.D. 400, pp. 171-193, Brill, Leiden.

Robbins, V.K., 1992,Jesus the teacher: A socio-rhetorical interpretation of Mark, Augsburg Fortress, Minneapolis.

Rothschild, C.K., 2004, Luke-Acts and the rhetoric of history: An investigation of early Christian historiography, Wissenschaftliche Untersuchungen sum Neuen Testament 2 reihe 175, Mohr Siebeck, Tübingen.

Rowe, G.O., 1997, 'Style', in S.E. Porter (ed.), Handbook of classical rhetoric in the Hellenistic Period 330 B.C.-A.D. 400, pp. 121-57, Brill, Leiden.

Rüger, H.P., 1969, "'Mit welchem Mass ihr messt, wird Ruch gemessen warden" [With the measure you use, it will be measured to warden Ruch]', Zeitschrift fur die Neutestamentliche Wissenschaft 60, 174-182.

Sheeley, S.M., 1992, Narrative asides in Luke-Acts, JSNT Suppl. 72 Sheffield Academic Press, Sheffield.

Shuler, P.L., 1982, A genre for the Gospels: The biographical character of Matthew, Fortress, Philadelphia.

Smith, M., 1951, Tannaitic parallels to the Gospels, Society of Biblical Literature, Philadelphia.

Smit Sibinga, J., 1997, 'Serta Paulina. On composition technique in Paul', Filología Neotestamentaria 10(19\&20), 35-54.

Squires, J.T., 1993, The plan of God in Luke-Acts, Society of New Testament Studies Monograph Series 76, Cambridge University Press, Cambridge.
Squires, J.T., 1998, 'The pan of God,' in I.H. Marshall \& D. Peterson (eds.), Witness to the Gospel: The theology of Acts, pp. 19-39, Eerdmans, Grand Rapids.

Stanton, G.N., 1974, Jesus of Nazareth in New Testament preaching, Cambridge University, Cambridge.

Stanton, G.N., 1989, The Gospels and Jesus, Oxford University Press, Oxford.

Stanton, G.N., 1993, A Gospel for a new people: Studies in Matthew, Westminster John Knox, Louisville.

Stanton, G.N., 2005, 'The Gospel traditions and early Christological reflection,' in J.D.G. Dunn \& S. McKnight (eds.), The historical Jesus in recent research, pp. 543-552, Eisenbrauns, Winona Lake.

Stern, D., 1991, Parables in Midrash: Narrative and exegesis in rabbinic literature, Harvard University Press, Cambridge.

Talbert, C.H., 1977, What is a Gospel? The genre of the canonical Gospels, Fortress, Philadelphia.

Vermes, G., 1984, Jesus and the world of Judaism, Fortress, Philadelphia.

Vermes, G., 1993, The religion of Jesus the Jew, Augsburg Fortress, Minneapolis.

Viviano, B.T., 1992, 'Beatitudes found among Dead Sea Scrolls', Biblical Archaeology Review 18(6), 53-55, 66.

Viviano, B.T., 1993a, 'Eight beatitudes at Qumran and in Matthew? A new publication from cave four', Svensk Exegetisk Årsbok 58, 71-84.

Viviano, B.T., 1993b, 'Eight beatitudes from Qumran', Bible Today 31(4), 219-224.

Vorster, W.S., 1990, 'Stoics and early Christians on blessedness', in D.L. Balch, E. Ferguson \& W.A. Meeks (eds.), Greeks, Romans, and Christians: Essays in honor of Abraham J. Malherbe, pp. 38-51, Fortress, Minneapolis.

Wills, L.M., 1997, The quest of the historical Gospel: Mark, John, and the origins of the gospel genre, Routledge, London.

Winter, B.W., 1997, Philo and Paul among the Sophists, Society for New Testament Studies Monograph Series 96, Cambridge University Press, Cambridge.

Witherington III, B., 1990, The Christology of Jesus, Augsburg Fortress, Minneapolis.

Ytterbrink, M., 2004, The third Gospel for the first time: Luke within the context of ancient biography, Lund University Centrum för Teologi och Religionsvetenskap, Lund. 